\title{
Risk Factors for Bruises and High Muscle pH in Lamb Carcasses of Tierra Del Fuego, Chilean Patagonia
}

\author{
Juan Antonio Tarumán1,2, Juan Pablo Smulders' ${ }^{1}$, Carmen Beatriz Gallo ${ }^{1 *}$ \\ ${ }^{1}$ Instituto de Ciencia Animal, Facultad de Ciencias Veterinarias, Universidad Austral de Chile, Valdivia, Chile \\ ${ }^{2}$ Programa Magister en Ciencias, Mención Salud Animal, Escuela de Graduados, Facultad de Ciencias Veterinarias, \\ Universidad Austral de Chile, Valdivia, Chile \\ Email: *cgallo@uach.cl
}

How to cite this paper: Tarumán, J.A., Smulders, J.P. and Gallo, C.B. (2018) Risk Factors for Bruises and High Muscle $\mathrm{pH}$ in Lamb Carcasses of Tierra Del Fuego, Chilean Patagonia. Open Access Library Journal, 5: e4291.

https://doi.org/10.4236/oalib.1104291

Received: December 27, 2017

Accepted: January 26, 2018

Published: January 29, 2018

Copyright $\odot 2018$ by authors and Open Access Library Inc.

This work is licensed under the Creative Commons Attribution International License (CC BY 4.0).

http://creativecommons.org/licenses/by/4.0/

\begin{abstract}
The aim of the study was to relate some pre-slaughter handling factors for lambs in a slaughterhouse, with the presence of bruises and high muscle $\mathrm{pH}$ in carcasses. Stocking density, transport distance and time, and type of slaughter (Conventional or Kosher) were registered in a sample of 1150 lambs that corresponded to 23 loads originated from different farms (Tierra del Fuego, Chilean Patagonia), distance and time of transport to slaughterhouse. The presence and characteristics of bruises were randomly registered in 50 carcasses per load, and muscle $\mathrm{pH}$ measured in loin and leg at $24 \mathrm{~h}$ postmortem. Transport distance fluctuated between 50 and $190 \mathrm{~km}$, transport time between 1.5 and 12 $\mathrm{h}$ and a mean stocking density of $164 \pm 32 \mathrm{~kg} / \mathrm{m}^{2}$ for lambs with an average live weight of $31 \pm 6 \mathrm{~kg}$ was recorded. Of all the carcasses $22.7 \%$ showed some degree of bruising and the loin was the most affected anatomical region, accounting for $47.1 \%$ of lesions. Transport time and live weight showed association $(\mathrm{P}<0.05)$ with bruising, with the most exposed animals being the heavier lambs ( $>30 \mathrm{~kg}$ ) and those travelling for more than $4 \mathrm{~h}$. In the leg a $\mathrm{pH}<5.8$ was predominant, while the predominant range in the loin was 5.8 to 6.3 . Transport time, presence and number of bruises were the factors that had a significant association $(\mathrm{P}<0.05)$ with $\mathrm{pH}$. Due to this association, both bruising and meat $\mathrm{pH}$ in lamb carcasses should be used at slaughter plants as indicators of meat quality and also of animal welfare.
\end{abstract}

\section{Subject Areas}

Animal Behavior, Veterinary Medicine, Zoology

\section{Keywords}

Lambs, Preslaughter Handling, Bruises, Muscle pH, Chilean Patagonia 


\section{Introduction}

Even though Chile has a reduced sheep population when compared with world class producers of lamb meat, it offers comparative advantages, especially in aspects such as health and extensive pasture production systems, for insertion in international markets [1]. Among the wide range of factors influencing the quality of meat are those related to the handling of animals on farm, during transport and prior to slaughter [2] [3] [4]. The export potential of the Chilean Patagonia and the increasingly demanding import markets make it necessary not only to focus on meat being a safe and healthy food, but also to consider that the animals have been managed under animal welfare approved systems [3]. This implies an adequate handling of animals during each of the stages along the lamb meat chain, particularly during pre-slaughter operations. Meat quality problems such as bruises on carcasses and high muscle $\mathrm{pH}$ are indicators of poor animal welfare during the pre-slaughter period, because they report situations of stress and probably pain that the animals have encountered before slaughter [5]. These problems also generate substantial economic losses for the lamb meat industry because they adversely affect the ethical quality of the product which in turn reduces the scope of potential target markets; they also affect the presentation and the yield of carcasses due to marks and trimmings that have to be made. Finally, these factors reduce the shelf life of the product and the possibilities of using technologies such as vacuum packaging [4]. The aim of this study was to relate some pre-slaughter handling factors for lambs in a slaughterhouse in Tierra del Fuego, Chilean Patagonia, with the presence of bruises and high muscle $\mathrm{pH}$ in carcasses.

\section{Material and Methods}

The data for this study were obtained from an export slaughterhouse in Tierra del Fuego, Chilean Patagonia, during the slaughter season (January to March) of 2013.

\section{Animals and carcasses}

To evaluate bruises, a sample of 1150 carcasses, corresponding to 50 lambs per each of 23 loads of lambs, was used. Each load consisted of 110 to 1104 lambs, which had the same origin (farm or estate in Tierra del Fuego), had been transported in the same journey (truck or truck plus trailer) and were then slaughtered after spending the same time in lairage at the slaughterhouse. To select the 50 carcasses within each load, a carcass was randomly picked, then a correlative order was followed until completing 50.

\section{Distance $(\mathrm{km})$ and transport time $(\mathrm{h})$}

The distance from each farm to the slaughterhouse and the estimated transport time of the trucks arriving with lambs were obtained from the records of the Report of Origin and Destination European Union and by using maps, both provided by the Agriculture and Livestock Service (SAG); these records indicated location and distance $(\mathrm{km})$ from supplier farms to slaughterhouse. Once 
the distance and transportation time were known, they were classified arbitrarily into two intervals, respectively: $\leq 100 \mathrm{~km}$ and $\geq 101 \mathrm{~km}$, and $\leq 4 \mathrm{~h}$ and $>4 \mathrm{~h}$.

\section{Stocking density during transport $\left(\mathrm{kg} / \mathrm{m}^{2}\right)$}

The stocking density was determined firstly using the information generated by the number of animals transported in each pen within the truck, and the space availability of each pen measuring width and length with a metric tape. Since lambs are not weighed on the farm or the slaughterhouse, the live weight of the lambs was estimated through the weight of the carcass to express the stocking density in $\mathrm{kg}$ live weight $/ \mathrm{m}^{2}$. This required the use of carcass dressing yields calculated in an earlier study within the same province where this study took place [6]; the yields were estimated to fluctuate between $38.9 \%$ and $41.1 \%$ depending on age and weight of the lambs.

\section{Lairage time $(\mathrm{h})$ prior to slaughter}

The lairage time was provided by the slaughterhouse and corresponded to the hours between the arrival of the animals from each load at the slaughterhouse until the start of the slaughtering process for the same load. For purposes of statistical analysis, they were separated into two groups according to lairage time: $\leq 12 \mathrm{~h}$ and $>12 \mathrm{~h}$.

\section{Type of slaughter}

A significant number of lambs at this slaughterhouse are processed by Kosher slaughter, hence without stunning prior to exsanguination. The Conventional slaughter included head to body electrical stunning. Of the 1150 lambs used for bruises and $\mathrm{pH}$ measurements, 750 corresponded to Kosher slaughter and 400 to Conventional slaughter.

\section{Observation and recording of bruises}

A visual inspection of the 1150 carcasses was performed to record the presence or absence of bruises and their characteristics according to the guidelines of Tarumán and Gallo [7], which basically indicate:

1) Grade of bruise: it was recorded according to the damage or destruction of tissues, using the Chilean Standard Classification of Bovine Carcasses [8], grade 1 being those bruises affecting only the subcutaneous tissue, grade 2 those reaching the subcutaneous and muscle tissue, and grade 3 those bruises that compromise the previous tissues plus bone tissue.

2) Extension of the bruise: every bruise was evaluated according to the approximate diameter of the affected area, considering 3 levels: $1=$ up to $5 \mathrm{~cm} \mathrm{di-}$ ameter, $2=6$ to $10 \mathrm{~cm}$ diameter and $3=$ larger than $10 \mathrm{~cm}$ diameter.

For carcasses with more than one bruise of different degree and extension, the prevailing criteria to classify the carcass were the larger bruises.

3) Anatomical location of the bruise: 4 anatomical regions were individualized: leg, shoulder, loin and chest-abdomen as indicated by Tarumán and Gallo [7].

4) Number of bruises: it was recorded by visual inspection of the carcass, counting the number of bruises in the entire carcass. 
Descriptive statistics was used for the analysis of results, to show frequencies and percentages. To determine the relationship between risk factors (transport time and transport distance, stocking density, live weight, lairage time, fasting time (transport plus lairage time) and type of slaughter) and the presentation of bruises in the carcasses, logistic regression was used.

\section{Recording of the $\mathrm{pH}$ in lamb carcasses}

The measurement of $\mathrm{pH}$ in the slaughterhouse under study is not a routine procedure. In this study, the $\mathrm{pH}$ was measured at $24 \mathrm{~h}$ postmortem only in carcasses from Conventional slaughter $(\mathrm{n}=400)$. It was not possible to obtain $\mathrm{pH}$ values from Kosher slaughter lambs because the forequarters of these animals were processed before $12 \mathrm{~h}$ postmortem and the hindquarters passed directly to deboning room. The $\mathrm{pH}$ was recorded in the Longissimus thoracis muscle (at the level of the $13^{\text {th }} \mathrm{rib}$ ) and in the leg between the Semitendinosus and Biceps femoris muscles, by direct insertion of a portable $\mathrm{pH}$ meter. For the descriptive analysis, the $\mathrm{pH}$ values obtained were grouped into 3 ranges as described by Watanabe et al. [9]: normal (<5.8), medium (5.8 - 6.3) and high (>6.3).

\section{Statistical analysis}

Data were entered into an Excel ${ }^{\circledR}$ matrix keeping separate Conventional slaughter lambs from Kosher lambs, and then exported to SPSS (Statistical Package for Social Science) version 16.0 software to be processed and analysed, obtaining frequencies, and position and dispersion statisticians regarding transport time and distance, stocking density, lairage time, presence and characteristics of bruises and $\mathrm{pH}$ measurements.

To study the relationship between various pre-slaughter factors and the percentage of bruised carcasses chi-square tests were performed. In the case of continuous variables such as $\mathrm{pH}$, normality tests (Shapiro-Wilk) were performed on the residuals of analysis models, being subsequently applied to the ANOVA for parametric variables, and Kruskal-Wallis for the nonparametric data, using statistical programs Statistix 8.0, SPSS and SAS.

To determine the relationship between risk factors and the presence of bruises in the carcasses, for each factor a univariate logistic regression analysis was primarily used to select the variables to be included in the multivariate binomial logistic regression analysis.

\section{Results and Discussion}

The transportation distance ranged between 50 and $190 \mathrm{~km}$, with a transport time between 1.5 and $12 \mathrm{~h}$; the maximum transport time corresponded to a journey with technical problems. Strappini et al. [10] reported earlier that although transport distance of sheep between farm and slaughterhouse in the Chilean Patagonia is relatively short (15 to $300 \mathrm{~km}$ ), there was no direct relationship between distance and travel time, which is similar to the findings of this study. This is because the roads are mostly gravel and generally in poor condition. In addition to the above, the inclement weather during some days (prolonged rainfall) in- 
creased the difficulty of trucks entering the farms and exiting once it was loaded with animals. In the case of the truck encountering technical problems, it was carrying a full load of lambs and could not move for about 6 hours due to inclement weather (heavy rain, with a consequent accumulation of mud); in addition to that, during this time there was an accumulation of animal waste on the different floors and the animals could not lie down due to the high stocking density. Finally, the lambs arrived fatigued to the slaughterhouse, with a high percentage of bruises and muscle $\mathrm{pH}$ values above the average found in this study. In conclusion, transport time and not transport distance should be considered as a main factor that could affect animal welfare and meat quality.

The stocking density used for lambs weighing between $23-41 \mathrm{~kg}$ (mean $31 \pm$ $6 \mathrm{~kg}$ ) averaged $164 \pm 32 \mathrm{~kg} / \mathrm{m}^{2}$. The stocking density increased along with age and estimated live weight of the lambs, because these factors are not considered by farmers or drivers for space availability calculations during transport; always a minimum of 12 and maximum of 15 lambs per pen were loaded. The fact that stocking densities are being taken to the limit instead of following the recommendations can be explained by economic reasons. According to both transporters and farmers, the maximum number of animals that can fit in a pen are loaded into trucks to reduce transportation costs. This condition should slowly improve with the legislation on the transport of livestock in Chile [11].

During lairage, lambs were held in pens with water available but no food. The lairage time for the lambs at the slaughterhouse ranged from 10.5 to $23.5 \mathrm{~h}$ (average $18 \pm 4 \mathrm{~h}$ ) and had no significant effect on the presence of bruises or high $\mathrm{pH}$. This lairage duration is similar to that previously found [12], which ranged from 5 to $26 \mathrm{~h}$, with an average of $14.6 \mathrm{~h}$. Considering the total fasting period of the lambs (lairage plus transport), this reached an average of $23 \pm 3 \mathrm{~h}$ (range 15.5 to $28.5 \mathrm{~h}$ ). The present legislation on the slaughter of animals for consumption [13] requires that animals should stay no longer than $24 \mathrm{~h}$ without food during lairage and therefore lairage times should tend to be reduced.

Kosher slaughter is permitted in some countries around the world such as Chile [14] [15], however others like Norway and Sweden have banned it and there are others who continue to debate this system [16]. Kosher slaughter causes the death of the animal directly by exsanguination, without prior stunning, by cutting the neck using a sharp knife that severs the trachea, oesophagus, jugular veins and carotid arteries, but without decapitating the animal [17]. According to Rosen [18] this method is quick and painless; also the heart continues to beat a few minutes after slaughter, so they argue that the exsanguination is optimal, and that consciousness is rapidly lost (approximately 2 seconds), irreversibly. The slaughterhouse in this study processes on average 200,000 head of sheep per season, most of which is exported, with Kosher slaughter being predominant over conventional slaughter during the first months of the lamb slaughtering season (January to March). The lambs destined for Kosher slaughter were subjected to a more complex handling; lambs with longer fleece were subjected to 
additional handling in the slaughterhouse, which consisted of passing them from the holding pens to the shearing pens, to shear the wool in the ventral area of the neck. The aim of this operation was to present lambs more cleanly to the slaughterer, to allow a better performance of his job; moreover, for Kosher slaughter it is necessary to have workers who can immobilize the lambs by hand before bleeding. Due to all this extra handling, a greater number of bruises on the carcasses were expected. However, the percentage of bruised carcasses was similar between Conventional slaughter (23.3\%) and Kosher (22.4\%) slaughter (Table $1)$. The same happened when comparing the number of bruises per carcass, observing a similar number of lesions in animals from Kosher and Conventional slaughter.

The $22.7 \%$ of bruised carcasses found, ranging from $6 \%$ to $42 \%$ in the 23 batches studied, was slightly lower than previous records [19] reporting in England $26 \%$ of bruises in lambs sent directly from farm to slaughterhouse and $31 \%$ in lambs that went through a livestock market prior to slaughter. The difference in bruise percentage between this study and that of Tarumán and Gallo [7], who recorded only $7.5 \%$ of bruises in lambs transported up to $400 \mathrm{~km}$ through the Magallanes Region, could be attributed to a road factor; the animals arriving to the slaughterhouse under the present study came exclusively from the island of Tierra del Fuego, where the state of the roads is much poorer and complex, usually only gravel, when compared to the obstacles faced by transport truck drivers anywhere else in the Magallanes Region. Ruiz de la Torre et al. [20] reported the effects of a moving vehicle in both good roads or smooth surface roads against secondary and coarse roads, and obtained differences in cortisol, heart rate and $\mathrm{pH}$ that favoured the animals transported on good roads. This study shows that there is also a risk for more bruises with bad roads that increase the journey time.

According to the depth of bruises in terms of tissues affected, it was possible to observe $18.2 \%$ of carcasses with bruises involving only subcutaneous tissue (grade 1), $4.3 \%$ of bruises involving subcutaneous plus muscular tissue (grade 2) and only $0.2 \%$ of bruises involving bone tissue (grade 3 ); the loin was the most affected anatomical region, with $47.1 \%$ of the lesions (Figure 1).These findings are similar to previous reports [7] [21] [22]. The loin is one of the most valuable parts of the carcass and when it is damaged the presentation of the product is negatively affected, its use is limited and the value of the carcass decreases due to

Table 1. Number of lambs, bruised carcasses and bruises observed according to the type of slaughter.

\begin{tabular}{cccc}
\hline & Total & Kosher & Conventional \\
\hline Number of lambs & 1150 & 750 & 400 \\
Number ( \% ) of bruised carcasses & $261(22.7 \%)$ & $168(22.4 \%)$ & $93(23.2 \%)$ \\
Number of bruises & 458 & 316 & 142 \\
Total bruises/bruised carcass & 1.75 & 1.88 & 1.52 \\
\hline
\end{tabular}




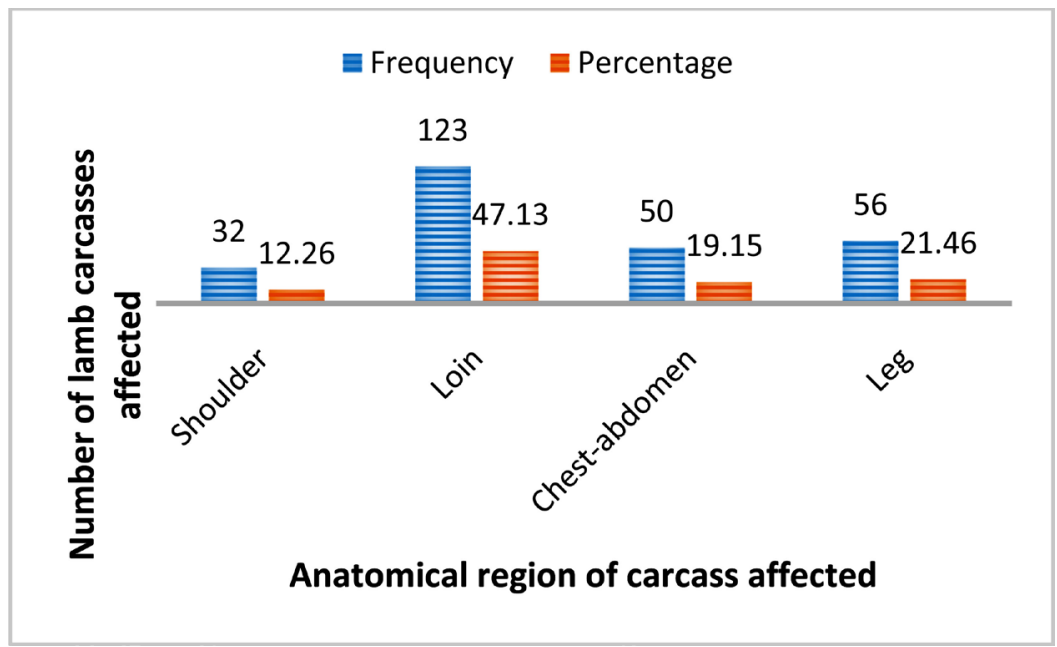

Figure 1. Frequency $\left(\mathrm{N}^{\circ}\right)$ and percentage (\%) of bruises by anatomical region affected for total bruised carcasses $(n=261)$.

Table 2. Logistic regression model of factors significantly associated with the presence of bruises on lamb carcasses.

\begin{tabular}{cccc}
\hline Risk factors & OR & 95\% CI & P \\
\hline Transport time & 1.595 & $1.204-2.113$ & 0.0012 \\
Live weight & 0.682 & $0.515-0.904$ & 0.0078 \\
\hline
\end{tabular}

trimmings. In terms of diameter, the most frequent bruises were those covering small areas $(<5 \mathrm{~cm})$, which is similar to the descriptions of other international studies that report most lamb bruises measuring only 2 to $4 \mathrm{~cm}$ [19] [23]. There was an average of 1.75 bruises per bruised carcass, ranging between 1 and 15 for the 261 bruised carcasses (Table 2). Most of the carcasses registered a single bruise (14.17\%) while a low percentage of carcasses presented 3 or more bruises, as observed by Jarvis and Cockram [19] in the United Kingdom. Transport time and live weight showed association $(\mathrm{P}<0.05)$ with the presence of bruises (Table 3 ) and the most exposed animals were those travelling for more than 4 hours, and heavier animals (>30 kg).

Regarding muscle $\mathrm{pH}$, Watanabe et al. [9] classified lamb muscle $\mathrm{pH}$ values as normal $(<5.8)$, intermediate (from 5.8 to 6.3 ) and high $(>6.3)$. The average $\mathrm{pH}$ values measured in lamb carcasses from conventional slaughter at $24 \mathrm{~h}$ postmortem were 5.73 and 5.78 in leg and loin, respectively. Mean $\mathrm{pH}$ values of up to 5.8 can be regarded as normal [9] [24]. In Chile, Vargas [22] reported a $\mathrm{pH}$ average of 5.73 to 5.74 in leg and loin. Other authors recorded an average $\mathrm{pH}$ of 5.59 to 5.62 for loin and leg, respectively [25]. Average values of $5.83 \pm 0.17$ are described in Uruguay for lambs [26]. However, $51 \%$ (loin) and $45.5 \%$ (leg) of the carcasses were classified within the intermediate range of $\mathrm{pH}$ (5.8 to 6.3) according to Watanabe et al. [9]. It was found that transport time, presence and number of bruises had a significant association $(\mathrm{P}<0.05)$ with muscle $\mathrm{pH}$ (Table 3), i.e. the $\mathrm{pH}$ increased with a longer transport time, and with the pres- 
Table 3. Effects of bruises, transport time, transport distance, extension of bruises, fasting time at the slaughterhouse, bruises grade and number on $\mathrm{pH} 24$ in loin and leg, in conventional slaughter of lambs.

\begin{tabular}{|c|c|c|c|c|c|c|c|}
\hline \multirow{2}{*}{ FACTOR } & \multicolumn{4}{|c|}{$\mathrm{pH}$ loin } & \multicolumn{3}{|c|}{$\mathrm{pH}$ leg } \\
\hline & & Media \pm S.D. & Inf Lim & Sup Lim & Media \pm S.E. & Inf Lim & Sup Lim \\
\hline \multirow{2}{*}{ Bruises } & Presence & $5.89^{\mathrm{a}} \pm 0.24$ & 5.83 & 5.95 & $5.83^{\mathrm{a}} \pm 0.2$ & 5.77 & 5.89 \\
\hline & Absence & $5.74^{\mathrm{b}} \pm 0.25$ & 5.71 & 5.78 & $5.7^{\mathrm{b}} \pm 0.24$ & 5.66 & 5.73 \\
\hline \multirow{2}{*}{ Transport time } & $\leq 4 \mathrm{~h}$ & $5.70^{\mathrm{a}} \pm 0.19$ & 5.65 & 5.75 & $5.67^{\mathrm{a}} \pm 0.21$ & 5,63 & 5.72 \\
\hline & $>4 \mathrm{~h}$ & $5.83^{\mathrm{b}} \pm 0.27$ & 5.79 & 5.87 & $5.76^{\mathrm{b}} \pm 0.25$ & 5.72 & 5.80 \\
\hline \multirow{2}{*}{ Transport distance } & $\leq 100 \mathrm{~km}$ & $5.82 \pm 0.08$ & 5.71 & 6.12 & $5.80 \pm 0.06$ & 5.68 & 6.03 \\
\hline & $>100 \mathrm{~km}$ & $5.78 \pm 0.27$ & 5.23 & 6.33 & $5.72 \pm 0.26$ & 5.20 & 6.27 \\
\hline \multirow{3}{*}{$\begin{array}{c}\text { Extension of } \\
\text { bruises }\end{array}$} & $\leq 5 \mathrm{~cm}$ & $5.87 \pm 0.24$ & 5.78 & 5.96 & $5.82 \pm 0.2$ & 5.74 & 5.89 \\
\hline & $6-10 \mathrm{~cm}$ & $5.94 \pm 0.25$ & 5.80 & 6.08 & $5.89 \pm 0.22$ & 5.77 & 6.01 \\
\hline & $>10 \mathrm{~cm}$ & $5.95 \pm 0.2$ & 5.67 & 6.20 & $5.78 \pm 0.08$ & 5.55 & 6.00 \\
\hline \multirow{2}{*}{$\begin{array}{l}\text { Fasting time at } \\
\text { slaughterhouse }\end{array}$} & $\leq 12 \mathrm{~h}$ & $5.78 \pm 0.27$ & 5.23 & 6.33 & $5.73 \pm 0.26$ & 5.20 & 6.27 \\
\hline & $>12 \mathrm{~h}$ & $5.77 \pm 0.28$ & 5.30 & 6.28 & $5.72 \pm 0.26$ & 5.27 & 6.14 \\
\hline \multirow[b]{2}{*}{ Bruise grade } & Grade 1 & $5.88 \pm 0.26$ & 5.80 & 5.95 & $5.82 \pm 0.22$ & 5.76 & 5.88 \\
\hline & $\begin{array}{c}\text { Grade } 2 \\
\text { and } 3\end{array}$ & $5.93 \pm 0.19$ & 5.81 & 6.06 & $5.86 \pm 0.14$ & 5.76 & 5.97 \\
\hline \multirow{2}{*}{ Number of bruises } & 1 & $5.86^{\mathrm{a}} \pm 0.23$ & 5.78 & 5.93 & $5.81^{\mathrm{a}} \pm 0.19$ & 5.75 & 5.87 \\
\hline & $>2$ & $5.98^{\mathrm{b}} \pm 0.22$ & 5.87 & 6.08 & $5.9^{\mathrm{b}} \pm 0.2$ & 5.80 & 5.99 \\
\hline
\end{tabular}

${ }^{a . b}$ Values with different letters for the same factor indicate significant difference $(\mathrm{P}<0.05 \%)$.

ence and number of bruises. This is in accordance with the fact that animals that are kept without food for long times (transport plus lairage), that are mishandled or stressed deplete their glycogen stores more easily [27]. These results in lambs are similar to the findings of Strappini et al. [28] regarding the relationship between $\mathrm{pH}$ and bruises in bovine carcasses. Results also agree with other Chilean studies [29] [30] where a positive association between transportation, fasting time and high $\mathrm{pH}$ in Chilean cattle has been found.

The relatively high incidence of carcasses with intermediate $\mathrm{pH}$ indicates that the quality of lamb meat could be affected even by short-term transport, as is the case of most of the sheep transport in Chile [10]. At present, there are no problems in terms of shelf life reduction because lamb meat is usually exported frozen to different national and overseas markets. However, the fact that no routine $\mathrm{pH}$ measurements are performed in the lamb carcasses, could be masking some quality problems which could become evident if technologies like vacuum packaging were used.

\section{Conclusion}

It can be concluded that, in general, the transport of sheep within the island of Tierra del Fuego is short distance, but transport duration may take up to $12 \mathrm{~h}$ for 
relatively short distances, negatively affecting the welfare of the animals and meat quality. Both the frequency of bruised carcasses $(22.7 \%)$ and the presence of carcasses with $\mathrm{pH}>5.8$ (48.25\%) suggest that these measurements should be considered by slaughter plants as indicators of animal welfare as well as meat quality. The implementation of preventive measures is required to reduce these meat quality problems, such as the training of personnel handling the animals in the slaughterhouse as well as training producers and transporters, instructing them about preslaughter handling and its consequences for lamb meat quality. The implementation of new transport and slaughter regulations within the Animal Protection Law [11] [13], which includes compulsory training for transporters and slaughterhouse operators should help in improving animal welfare and lamb meat quality.

\section{Acknowledgements}

The authors would like to thank Frigorífico Patagonia S.A. and Servicio Agrícola y Ganadero (SAG) for their collaboration for this study.

\section{References}

[1] Sales, F. (2005) Ultrasonografía en ovinos: optimizando el uso de las praderas. Instituto de Investigación Agropecuaria, Ministerio de Agricultura, Chile. Centro Regional de Investigación Kampenaike. Boletín INIA-N ${ }^{\circ} 132$.

[2] Grandin, T. (1994) Farm Animal Welfare during Handling, Transport and Slaughter. Animal Welfare Forum, 204, 372-377.

[3] Warriss, P. (2000) Meat Science: An Introductory Text. CABI Plublishing, Oxon, UK.

[4] Gallo, C. (2009) Bienestar animal y buenas prácticas de manejo animal relacionadas con la calidad de la carne, Capítulo 13. In: Bianchi, G. and Feed, O., Eds., Introducción a la ciencia de la carne, Hemisferio Sur, Montevideo, Uruguay, 455-494.

[5] Gallo, C.B. and Huertas, S.M. (2016) Main Animal Welfare Problems in Ruminant Livestock during Preslaughter Operations: A South American View. Animal, 10, 342-348. https://doi.org/10.1017/S1751731115001597

[6] Gutiérrez, J.M. (2009) Desempeño productivo y características de la canal de corderos Corriedale faenados a distintos tiempos post destete en Tierra del Fuego, Chile. Memoria de título, Escuela de Medicina Veterinaria, Universidad Austral de Chile, Valdivia, Chile.

[7] Tarumán, J. and Gallo, C. (2008) Contusiones en canales ovinas y su relación con el transporte. Archivos de Medicina Veterinaria, 40, 275-279. https://doi.org/10.4067/S0301-732X2008000300008

[8] INN, Instituto Nacional de Normalización, Chile (2002) Norma Chilena de Tipificación de Canales Bovinas. NCH.1306.Of. 2002.

[9] Watanabe, A., Daly, C. and Devine, C. (1996) The Effects of the Ultimate pH of Meat on Tenderness Changes during Ageing. Meat Science, 42, 67-78. https://doi.org/10.1016/0309-1740(95)00012-7

[10] Strappini, A., Gallo, C., Cáraves, M., Barrientos, A., Allende, R., Chacón, F. and Briones, I. (2007) Relevamiento preliminar del transporte de ganado ovino en la XII Región, Chile: vehículos y manejo de los animales durante la descarga. Proceedings 
XXI Congreso Anual de la Sociedad Chilena de Producción Animal, 191-192.

[11] MINAGRI, Ministerio de Agricultura, Chile (2013) Ministerio de Agricultura. Decreto No30, Reglamento sobre protección del ganado durante el transporte.

[12] Pantanalli, C. (2008) Características de pH de las canales ovinas faenadas en la planta Mañihuales de Coyhaique y su relación con distancia de procedencia y tiempo de espera de los animales. Memoria de título, Escuela de Medicina Veterinaria, Universidad Austral de Chile, Valdivia, Chile.

[13] MINAGRI, Ministerio de Agricultura, Chile (2013) Ministerio de Agricultura. Decreto No28, Reglamento sobre protección de los animales que provean de carne, pieles, plumas y otros productos al momento del beneficio en establecimientos industriales.

[14] MINAGRI, Ministerio de Agricultura, Chile (2009) Reglamento de funcionamiento de mataderos, cámaras frigoríficas y centrales de desposte y fija equipamiento mínimo de tales establecimientos. Decreto No 94. Publicado en el Diario Oficial 2 de junio de 2009.

[15] OIE, World Organization for Animal Health (2015) Terrestrial Animal Health Code, Chapter 7, Animal Welfare.

[16] Anil, M.H., Yesildere, T., Aksu, H., Matur, E., McKinstry, J.L., Weaver, H.R., Erdogan, O., Hugues, S. and Mason, C. (2006) Comparison of Halal Slaughter with Captive Bolt Stunning and Neck Cutting in Cattle: Exsanguination and Quality Parameters. Animal Welfare, 15, 325-330.

[17] Dalmau, A., Llonch, P. and Velarde, A. (2012) Sacrificio religioso de animales para consumo. In: Mota-Rojas, D., Huertas-Canen, S.M., Guerrero-Legarreta, I. and Trujillo-Ortega, M.E., Eds., Bienestar animal: Productividad y calidad de la carne, 2nd Edición, Capítulo 23, Elsevier, México, 427-448.

[18] Rosen, S. (2004) Physiological Insights into Shechita. Veterinary Record, 154, 759-765. https://doi.org/10.1136/vr.154.24.759

[19] Jarvis, A. and Cockram, M. (1995) Handling of Sheep at Markets and the Incidence of Bruising. Veterinary Record, 136, 582-585. https://doi.org/10.1136/vr.136.23.582

[20] Ruiz de la Torre, J., Velarde, A., Diestre, A., Gispert, M., Hall, S., Broom, D.M. and Manteca, X. (2001) Effects of Vehicle Movements during Transport on the Stress Responses and Meat Quality of Sheep. Veterinary Record, 148, 227-229. https://doi.org/10.1136/vr.148.8.227

[21] Cockram, M. and Lee, R. (1991) Some Preslaughter Factors Affecting the Occurrence of Bruising in Sheep. British Veterinary Journal, 147, 120-125. https://doi.org/10.1016/0007-1935(91)90101-R

[22] Vargas, R. (2009) Efectos de dos densidades de carga durante el transporte prolongado y dos tiempos de reposo previo al faenamiento sobre algunas características de la canal en corderos. Memoria de título, Escuela de Medicina Veterinaria, Universidad Austral de Chile, Valdivia.

[23] Jarvis, A., Cockram, M. and McGilp, I. (1996) Bruising and Biochemical Measures of Stress, Dehydration and Injury Determined at Slaughter in Sheep Transported from Farms or Markets. British Veterinary Journal, 152, 719-722. https://doi.org/10.1016/S0007-1935(96)80125-4

[24] Devine, C.E., Lowe, T.E., Wells, R.W., Edwards, N.J., Hocking Edwards, J.E., Starbuck, T.J. and Speck, P.A. (2006) Pre-Slaughter Stress Arising from On-Farm Handling and Its Interactions with Electrical Stimulation on Tenderness of Lambs. Meat Science, 73, 304-312. https://doi.org/10.1016/j.meatsci.2005.12.005

[25] De la Fuente, J., Pérez, C., Vieira, C., Sánchez, M., González de Cháverri, E., García, 
M., Álvarez, I. and Díaz, M. (2006) The Effect of Transport on pH Evolution of Different Muscles in Suckling Lambs. Proceedings 52nd International Congress of Meat Science and Technology, Dublin, 13-18 August 2006, 177-178.

[26] INIA, Instituto Nacional de Investigación Agropecuaria (2003) Primera auditoría de calidad de la cadena cárnica ovina del Uruguay. Uruguay.

[27] Ferguson, D.M. and Warner, R.D. (2008) Have We Underestimated the Impact of Pre-Slaughter Stress on Meat Quality in Ruminants? Meat Science, 80, 12-19. https://doi.org/10.1016/j.meatsci.2008.05.004

[28] Strappini, A., Frankena, K., Metz, J., Gallo, C.B. and Kemp, B. (2010) Prevalence and Risk Factors for Bruises in Chilean Bovine Carcasses. Meat Science, 86, 859-864. https://doi.org/10.1016/j.meatsci.2010.07.010

[29] Gallo, C., Lizondo, G. and Knowles, T.G. (2003) Effects of Journey and Lairage Time on Steers Transported to Slaughter in Chile. Veterinary Record, 152, 361-364. https://doi.org/10.1136/vr.152.12.361

[30] Amtmann, V.A., Gallo, C., Van Schaik, G. and Tadich, N. (2006) Relationships between Ante-Mortem Handling, Blood Based Stress Indicators and Carcass $\mathrm{pH}$ in Steers. Archivos de Medicina Veterinaria, 38, 259-264. 